Indian J Pediatr 1992; $59: 735-739$

\title{
Persistent Pulmonary Arterial Hypertension of the New Born
}

\author{
A. Narang, O.N. Bhakoo, P.M.C. Nair and Vineet Bhandari \\ Neonatal Division of the Department of Pediatrics, Postgraduate Institute of Medical \\ Education \& Research, Chandigarh
}

\begin{abstract}
Persistent puimonary hypertension of the newborn (PPHN) characterised by right to left shunting with intense cyanosis is difficult to manage, and in the best of centres carries a 40-60 percent mortality. We report our one year's experience of managing six neonates with PPHN.

There were 5 males and 1 female with mean birth weight of $2.59 \pm 0.487$ $\mathrm{kg}$ and gestation period $39 \pm 2.0$ wks and 1 minute Apgar score $2.8 \pm 2.1$. Four to six babies were born by cesarean section and 3-6 babies had aspiration pneumonia. All babies presented within 12 hours of age (mean $5.08 \pm$ $5 \mathrm{hrs}$ ) with intense cyanosis and respiratory distress. Diagnosis were confirmed in all by (a) hyperoxia test, (b) simultaneous determination of preductal and postductal $\mathrm{paO}_{2}(c)$ contrast echocardiography and (d) hyperoxiahyperventilation test. Babies were managed with hyperventilation using mean ventilatory rates of $100 \pm 45$ per minute, an inspired oxygen concentration of $100 \%$, peak inspiratory pressures $27 \pm 9 \mathrm{~cm}$ of $\mathrm{H}_{2} \mathrm{O}$, and expiratory pressures $5 \pm 1.6 \mathrm{cms}$ of $\mathrm{H}_{2} \mathrm{O}$, and mean air way pressures of $10.4 \pm 2.7$ $\mathrm{cms} \mathrm{H}_{2} \mathrm{O}$. Alkali therapy was used in 3 of the six babies whereas low dose dopamine was infused in all six babies. Inspite of aggressive ventilatory therapy, only 3 out of 6 babies could be salvaged.
\end{abstract}

Key words : Persistent pulmonary hypertension; Hyperventilation.

Persistent pulmonary hypertension in the newborn (PPHN) is a syndrome characterised by severe, labile cyanosis arising from right to left shunting at the level of the foramen ovale or ductus arteriosus secondary to high pulmonary vascular resistance. ${ }^{1,2}$ The clinical hallmark is the presence of severe labile hypoxemia disproportionate to the extent of pulmonary parenchymal disease in association with a structurally normal heart.

Reprint requests : Dr. O.N. Bhakoo, Professor of Neonatology (Pediatrics), Postgraduate Institute of Medical Education \& Research, Chandigarh-160012.
Because of the severe pulmonary hypertension and extremely labile hypoxic 'flip-flop', management of this condition even in the best of centres is very difficult and results in a mortality rate of around $40-60 \%$ in severe cases. $^{3}$

There is only one report of PPHN from India. We report our one year's experience in managing PPHN through intensive care, highlighting the problems encountered in their management.

\section{MATERIAL AND METHODS}

During September 1989 to August, 1990, 
437 babies were admitted to the neonatal intensive care unit of the Deparment of Pediatrics, Nehru Hospital, Postgraduate Institute of Medical Education and Research, Chandigarh $\& 90$ babies were ventilated for varying indications during the same period. Six babies were diagnosed to be having PPHN. In these babies with severe cyanosis, and labile hypoxemia, the diagnosis of PPHN was confirmed after performing hyperoxia test, pre and postductal arterial oxygen tension, contrast echocardiography and hyperoxia-hyperventilation test. Once the diagnosis was confirmed, these babies were hyperventilated in $100 \%$ oxygen with ventilatory rates $60-150$ per minute to achieve an arterial oxygenation of $50-75 \% \mathrm{~mm}$ of $\mathrm{Hg}$ and $\mathrm{PaCO}_{2}$ of less than $40 \mathrm{~mm} \mathrm{Hg}$. Meticulous nursing, minimal handling and inotropic agent's use were the other modalities of care in these neonates.

\section{RESULTS}

During one year study period, $20.5 \%$ of the NICU admissions were provided ventilatory assistance for varying indications. Six babies (1.4\%) of all NICU admissions were diagnosed to have PPHN based on the standard diagnostic criteria. Tables 1 and 2 summarises the clinical features, management and outcome of these patients. There were 5 males and 1 female with mean birth weight $2590 \pm 487 \mathrm{gm}$ and gestation of $39 \pm 2.0$ wks. All babies had birth asphyxia. PPHN was diagnosed at $5.08 \pm 5.1$ hours age. These babies were ventilated with mean peak inspiratory pressures (PIP) of $27 \pm 9 \mathrm{~cm} \mathrm{H} \mathrm{O}_{2} \mathrm{O}$ with positive and expiratory pressure (PEEP) of $5.0 \pm 1.6 \mathrm{cms}$ and mean airway pressure (MAP) of $10.4 \pm 2.7$ at ventilatory rates of $100 \pm 45$ per minute with $100 \%$ oxygen. Inotropic agent (Dopamine) was given to all six, whereas three babies also received high dose alkali therapy. Only 2 out of 6 babies could be successfully weaned off the ventilation, and one baby though improved of PPHN but died subsequently due to hospital acquired fungal infection.

\section{DISCUSSION}

Primary pulmonary hypertension of the newborn (DPHN) generally occurs in full term neonates having intense cyanosis due to pulmonary hypertension, causing right to left shunt through ductus arteriosus and/or foramen ovale causing severe hypoxemia. Anatomically pulmonary vasculature may be maladapted, excessively muscularised or underdeveloped. ${ }^{1.2,4}$

PPHN though commonly associated with perinatal asphyxia and meconium aspiration syndrome, ${ }^{5}$ it may be associated with group B sterptococcal pneumonia, idiopathic increased airway resistance, diaphragmatic hernia, myocarditis, pulmonary hypoplasia and non-bacterial endocardial thrombosis. ${ }^{5-12}$

PPHN may present early (at birth) or moderately delayed (4-12 hours of age) or late (after 12 hours age). Babies with early presentation are often severely asphyxiated, whereas moderately delayed presentation are associated with MAS or other parenchymal lung disease like group $B$, beta strept. infection. The late presentation of PPHN generally occurs in association with pulmonary pathology leading to progressive increase in airway resistance. ${ }^{13}$ In our patients, 5-6 were severely asphyxiated, 3 presented within 3 bours of age and the others presented within 12 hours age. Diagnosis of PPHN is based on hyperoxia test, comparison of pre and postductal $\mathrm{paO}_{2}$, contrast echocardiography and hyperoxia hyperventilation test done serialy. Hyperoxia hyperventilation test aiso 
Table 1. PPHN Clinical Data

\begin{tabular}{lccccccccc}
\hline $\begin{array}{l}\text { Name } \\
\text { of baby }\end{array}$ & CR No. & Sex & $\begin{array}{c}\text { Weight } \\
\text { (gms) }\end{array}$ & $\begin{array}{c}\text { Gestation } \\
\text { (wks) }\end{array}$ & $\begin{array}{c}\text { Mode of delivery } \\
\text { indication }\end{array}$ & $\begin{array}{c}\text { Apgar score } \\
\text { at l',5 }\end{array}$ & $\begin{array}{c}\text { Meconium } \\
\text { aspiration }\end{array}$ & $\begin{array}{c}\text { Onset of } \\
\text { PPIIN }\end{array}$ & $\begin{array}{c}\text { Duration } \\
\text { of PPHN }\end{array}$ \\
\hline $\mathrm{S}$ & 021881 & $\mathrm{M}$ & 2500 & 40 & Low mid cavity & 0,5 & + & $40 \mathrm{~min}$ & $96 \mathrm{hrs}$ \\
$\mathrm{S}$ & 640251 & $\mathrm{~F}$ & 2400 & $40^{+6}$ & LSCS & 3,7 & + & $6 \mathrm{hrs}$ & $56 \mathrm{hrs}$ \\
$\mathrm{H}$ & 633977 & $\mathrm{M}$ & 3200 & $40^{+2}$ & LSCS & 3,5 & - & $12 \mathrm{hrs}$ & $96 \mathrm{hrs}$ \\
$\mathrm{I}$ & 641901 & $\mathrm{M}$ & 3100 & $39^{+5}$ & LSCS & 6,8 & - & $0.1 \mathrm{hr}$ & $40 \mathrm{hrs}$ \\
$\mathrm{I}$ & 640034 & $\mathrm{M}$ & 1882 & 35 & LSCS & 1,4 & - & $10 \mathrm{hrs}$ & $38 \mathrm{hrs}$ \\
$\mathrm{M}$ & 030285 & $\mathrm{M}$ & 2500 & $37^{+2}$ & NVD & $?$ & - & $21 / 2 \mathrm{hrs}$ & \\
\hline
\end{tabular}

Table 2. PPHN--Diagnostic Tests and Management

\begin{tabular}{|c|c|c|c|c|c|c|c|c|}
\hline $\begin{array}{l}\text { Name of } \\
\text { baby }\end{array}$ & $\begin{array}{l}\text { Hyperoxia } \\
\text { test }\end{array}$ & $\begin{array}{l}\text { Preductal } \\
\text { postductal } \\
\mathrm{PaO}_{2} \\
\text { difference } \\
15 \mathrm{~mm} \mathrm{Hg}\end{array}$ & $\begin{array}{l}\text { Contrast } \\
\text { Echocardio- } \\
\text { graphy }\end{array}$ & $\begin{array}{l}\text { Hyperoxia } \\
\text { hyper } \\
\text { ventilation } \\
\text { test }\end{array}$ & $\begin{array}{l}\text { Ventilator } \\
\text { settings } \\
\mathrm{FiO}_{2} / \mathrm{PIP} / \\
\text { PEEP/Rate/ } \\
\text { MAP }\end{array}$ & $\begin{array}{l}\text { Alkali } \\
\text { therapy }\end{array}$ & Dopamine & Outcome \\
\hline S & + & + & NA & + & $100 / 17 / 2 / 150 / 7$ & -- & + & $\begin{array}{l}\text { Recovered } \\
\text { Died at } 11 \\
\text { days age }\end{array}$ \\
\hline$s$ & + & + & $\mathrm{NA}$ & + & $100 / 30 / 3 / 76 / 12$ & + & + & $\begin{array}{l}\text { Expired } \\
\text { Age } 62 \text { yrs }\end{array}$ \\
\hline H & + & $\mathrm{NA}$ & $\begin{array}{l}\text { R-I shunt } \\
\text { across atrial } \\
\text { level }\end{array}$ & + & $100 / 18 / 5 / 65 / 9$ & - & + & Recovered \\
\hline $\mathrm{P}$ & + & + & $\begin{array}{l}\text { R-L shunt at } \\
\text { atrial and } \\
\text { ductal level }\end{array}$ & + & $100 / 35 / 4 / 160 / 10$ & + & + & $\begin{array}{l}\text { Expired } \\
\text { Age } 42 \text { hrs }\end{array}$ \\
\hline I & + & NA & $\mathrm{NA}$ & + & $100 / 35 / 6 / 150 / 14$ & + & + & $\begin{array}{l}\text { Expired } \\
\text { Age } 411 / 2 \\
\text { hrs }\end{array}$ \\
\hline M & + & NA & $\begin{array}{l}\text { R-L shunt } \\
\text { at atrial and } \\
\text { ductal level }\end{array}$ & + & Hand ventilation & - & + & Recovered \\
\hline
\end{tabular}

helps in excluding congenital cyanotic heart disease, and determining the inflation pressures required for ventilation to achieve the critical $\mathrm{paCO}_{2}$.

Management of such infants revolves round judicious combination of mechanical ventilation, pharmacological intervention and nursing care. Fox and Duara ${ }^{13}$ had recommended the hyperventilation approach producing respiratory alkalosis thereby achieving lower pulmonary pressures. The primary aim is to lower $\mathrm{paCO}_{2}$ to a 'critical level' so as to achieve reduction in pulmonary artery pressures and subsequent reversal of right to left shunt. Duara et al ${ }^{14}$ bad recommended ventilatory settings using higher peak inspiratory pressures (PIP), low cnd cxpiratory pressures (PEEP) with inspiratory expiratory ratios of $1: 1$ and $100 \%$ oxygen. While ventilating these babies, a "transition 
phase' is reached within 1-3 days after which ventilation becomes much easier. While weaning, PIP should be decreased first using caution of not altering the $\mathrm{FiO}_{2}$ and PIP too suddenly because of increased vascular reactivity of these babies.

Fox ${ }^{3}$ while using this aggressive approach of management in their 54 patients showed a survival of $56 \%$ with mean duration of ventilation of 5-9 days. We, in our patients, could successfully wean off 3 out of 6 patients using similar approach. One of our three neonates later on died of hospital acquired fungal infection on day 11.

Alternative to hyperventilation has also been suggested by many workers. ${ }^{16-20}$ Wung et $\mathrm{al}^{16}$ while managing 15 neonates with extensive use of pharmacological agents but without hyperventilation achieved a success rate of $66 \%$. Dworetz et a ${ }^{17}$ similarly showed a success rate of $90 \%$ using conservative approach which was comparable to the results shown by others using extra-corporeal membrane oxygenation (ECMO).

Tolazoline and dopamine have been extensively used as pharmacological agents in the management of PPHN. ${ }^{6,19-22}$ Because of its high adverse reactions, Tolazoline is now recommended only as an adjunct to low dose dopamine therapy. However, in India because of its non-availability, we did not use Tolazoline in any of our patients. Use of other pharmacological agents like prostaglandins, nitroprusside, bradykinin, isoprotenol, morphine, leukotrienes and high dose bicarbonate therapy are still in experimental stages in the management of PPIN.

\section{REFERENCES}

1. Henry GW. Noninvasive assessment of cardiac function and pulmonary hypertension in PPHN. Clin Perinatol 1984; 11 : 627-
640.

2. Geggel RL, Reid LM. The structural basis of PPHN. Clin Perinatol 1984; 11 : 525549.

3. Fox WW. Mechanical ventilation in the management of PPHN. In: Proceedings of the 83rd Ross Conference on Cardiovascular Sequelae of Asphyxia in the Newborn 1982; pp. 102.

4. Peckham GH, Fox WW. Physiologic fáctors affecting pulmonary artery pressure in infants with persistent pulmonary hypertension. J Pediatr 1978; 93 : 10051010.

5. Fox WW, Gewitz MH, Sinwiddie R et al. Pulmonary hypertension in perinatal aspiration syndrome. Pediatrics $1977 ; 59: 205$. 208

6. Drummond WH, Gregory GA, Heyman MA et al. The independent effects of hyperventilation, tolazoline and dopamine on infants with persistent pulmonary hypertension. J Pediatr 1981; 98 : 603-611.

7. Shutack JG, Moomjian AS, Fox WW et al. Severe obstructive airway disease associated with pulmonary artery hypertension in the neonate. Pediatric Res $1979 ; 13: 541$ 543.

8. Gersony WM. Persistence of the fetal circulation: A commentary. $J$ Pediatr 1973; $82: 1103$.

9. Bloss RS, Turmen T, Beardmore HE st al. Tolazoline therapy for persistent pulmonary hypertension after congential diaphragmatic hernia repair. J Pediatr 1980; 97 : 984-986.

10. Morrow WR, Haas JE, Benjamin DR. Nonbacterial endocardial thrombosis in neonates: Relationship to persistent fetal circulation. J Pediatr 1982; 100 : 117-119.

11. Swischuck LE, Richardson CJ, Nichols MM et al. Primary pulmonary hypoplasia in the neonates. $J$ Pediatr 1979; 95 : 573577.

12. Drummond WH, Peckham GJ, Fox WW. The clinical profile of the newborn with persistent pulmonary hypcrtension. Obser- 
vations in 19 affected neonates. Clin Pediatr 1977 ; 16 : 335-340.

13. Fox WW, Duara S. Persistent pulmonary hypertension of the neonate: Diagnosis and clinical management. J Pediatr 1983; 103 : 505-514.

14. Duara S, Gewitz MH, Fox WW. Use of mechanical ventilation for clinical management of PPHN. Clin Perinatol 1984; 11 : 641-652.

15. Valdes-Cruz LM, Dudell GG, Ferrara A. Utility of $\mathrm{M}$-mode echocardiography for early identification of infants with PPHN. Pediatrics 1981; 68 : 515-518.

16. Wung JT, James LS, Kilchersky E et al. Management of infants with severe respiratory failure and persistence of fetal circulation without hyperventilation. Pediatrics 1985; $76: 488-494$.

17. Dworetz AR, Gladstone IM, Moya FR et al. Survival of infants with severe persistent pulmonary hypertension (PPH) without extra corporeal membrane oxygenation - an update. Pediatr Res 1989; $25: 214 \mathrm{~A}$, Abstract No. 1260.

18. Rosenbaum $\mathrm{J}$, Barrios P, Canter $\mathrm{C}$ et al. Is hyperventilation appropriate therapy for all infants with PPHN? Pediatr Res 1989; 25 : 229A, Abstract No. 1356.

19. Drummond WH, Lock JE. Neonatal pulmonary vasodilation drugs. Current status. Der Pharmacol Ther 1984; $7: 1-20$.

20. Stevenson DK, Kasting DS, Durnall RA et al. Refractory hypoxemia associated with neonatal pulmonary disease, the use and limitations of tolazoline. J Pediatr 1979; $95: 595-599$.

21. Drummond WII. Cardiotonic therapy in management of PPHN. Clin Perinatol 1984; $11: 715-728$.

22. Kulik TJ, Lock JE. Pulmonary vasodilator therapy in PPHN. Clin Perinatol 1984; 11 : 693-701.

\section{VECTOR CONTROL IN URBAN COLONIES}

Owing to population growth, poor levels of hygiene, and increasing urban poverty, the urban environment in many developing countries is rapidly deteriorating. Densely packed housing in shanty towns or slums, and inadequate drinking-water supplies, garbage collection scrvices, and surface-water drainage systems combine to create favourable habitats for the proliferation of vectors and reservoirs of communicable diseases. As a consequence, vector borne diseases such as malaria, lymphatic filariasis and dengue are becoming major public health problems associated with rapid urbanization in many tropical countries.

The problems in controlling these diseases and eliminating vectors and pests can be resolved by decision-makers and urban planners by moving away from the concept of "blanket" applications of pesticides towards integrated approaches. Sound environmental management practices and community education, and firm participation form the mainstay of some of the most outstanding successes in this area. On the basis of these examples, it is argued that the municipal authorities need to apply a flexible methodology, which must be based on the possibilities of mobilizing community resources, with minimal reliance on routine pesticidal spraying. In this way, vector control becomes a byproduct of human development in the city environment. This is now a true challenge. 